Modern Asian Studies 52, 5 (2018) pp. 1664-1691. (C) Cambridge University Press 2018 doi:10.1017/Soo26749X160oo810 First published online 21 June 2018

\title{
Cross-Border Intimacies: Marriage, migration, and citizenship in western India*
}

\author{
FARHANA IBRAHIM \\ Indian Institute of Technology, Delhi \\ Email:fibrahim@hss.iitd.ac.in
}

\begin{abstract}
This article examines intersections between sexuality, migration, and citizenship in the context of cross-border and cross-region marriage migration in Kutch, Gujarat, to underscore that women's mobility across borders is one site on which national cultural and political anxieties unfold. It argues that contemporary crossregion marriage migration must be located within the larger political economy of such marriages, and should take into account the historical trajectories of marriage migration in particular regions. To this end, it examines three instances of marriage migration in Kutch: the princely state's marriages with Sindh, nineteenth-century marriages between merchants from Kutch and women from Africa, and contemporary marriage migration into Kutch from Bengal. The article asks whether the relative evaluation of these marriages by the state can be viewed in relation to the settlement policies undertaken after partition, where borderlands were to be settled with those who were deemed loyal citizens. Finally, by historicizing marriage-as structure, but also aspirational categoryit seeks to move away from the singularity of marriage as framed in the dominant sociological discourse on marriage in South Asia.
\end{abstract}

\section{Introduction: marriage, migration, and citizenship}

Borderlands are not the out-of-the-way places they tend to occupy on maps; for states, they typically are the centrepiece of political attention. Recent work on cross-border mobility challenges the notion of a centralized state's control over its territorial borders and proposes

* I am grateful to the Indian Institute of Technology's IRD grant for supporting fieldwork related to this work. I thank Arudra Burra, Radhika Gupta, Ravinder Kaur, and Simona Sawhney for discussion on a draft of the article. 
new ways of envisaging a region. ${ }^{1}$ In the context of South Asia, contemporary cross-border migration builds on networks of trade, labour, and marriage that have endured across partition, and is a potent reminder that new borders drawn up in 1947 or 1971 were not the definitive hiving-off of territory so much as the inauguration of new regimes of citizenship and border management on the part of the state, and of new expressions of identity and belonging for its citizens. This article examines the intersections between sexuality, migration, and citizenship in the context of cross-border and cross-region marriage migration in Kutch, Gujarat, to underscore that women's mobility across borders is one of the sites on which political anxieties regarding the nation state unfold. ${ }^{2}$ The migration and subsequent marriage of predominantly Muslim women from West Bengal into Kutch are typically identified in popular and media discourses as 'forced' marriage, ${ }^{3}$ or 'trafficking'. ${ }^{4}$ On the other hand, the migration of predominantly Hindu women into Kutch across its western border with Pakistan, often illegal in strictly bureaucratic terms, as they lack formal travel documents, is reported differently; while most Bengalispeaking migrants, regardless of their religion, or their point of origin (namely whether they are from West Bengal or Bangladesh) are identified by the shorthand 'Bangladeshi', and therefore 'illegal' or 'trafficked', in the case of migrants from Pakistan's Sindh province, there is a further sorting process: while Muslims are viewed as 'illegal infiltrators', Hindus tend to be 'accommodated' as citizens. I argue that this relative evaluation of cross-border mobility must be viewed in a broader historical and sociological perspective to ask: under what historical and discursive conditions does the migration of women for marriage lend itself to an evaluation of citizenship and belonging in contemporary India? To answer this question, I will argue first that

${ }^{1}$ See, for example, D. Gellner (ed.), Borderland Lives in Northern South Asia: NonState Perspectives, Duke University Press, Durham, 2013; W. van Schendel, The Bengal Borderland: Beyond State and Nation in South Asia, Anthem Press, London, 2005.

${ }^{2}$ See, for example, R. Andrijasevic, 'Beautiful Dead Bodies: Gender, Migration and Representation in Anti-Trafficking Campaigns', Feminist Review, vol. 86, 2007, pp. 24-44.

${ }^{3}$ http://timesofindia.indiatimes.com/city/ahmedabad/Forced-brides-Kutchipeople-explore-new-matchmaking-options/articleshow/45737720.cms, accessed 13 April 2018.

${ }^{4}$ This is the case not just in Kutch, but also in the other parts of India where Bengali women have married local men, such as Uttar Pradesh. See T. Blanchet, 'Bangladeshi Girls Sold as Wives in North India', Indian Journal of Gender Studies, vol. 12 (2\&3), 2005, pp. 305-34. 
contemporary cross-region marriage migration must be located within the larger political economy of such marriages, and should take into account historical trajectories of marriage migration in particular regions. To this end, I examine three instances of cross-border and cross-region marriage migration in Kutch. ${ }^{5}$ These instances range from royal marriages in the princely state of Kutch, nineteenthcentury marriages between Kutchi merchants and African women, and, finally, contemporary marriages into Kutch of women from Bengal and Sindh. Second, I ask: what do contemporary debates over citizenship, nationality, and marriage share with similar debates that have occurred before? What does a comparative study of marriage migration tell us about the state's deployment of sexuality in the construction of the citizen, as it identifies some women more worthy than others to be admitted into the fold of the nation-as-family?

Recent ethnographic literature on marriage migration is important not only because it genders our understanding of contemporary transnational migration, but also because it examines the effects of crossing borders on the institution of marriage itself, as traditional gender and family codes are often reformulated in the encounter with nation state and immigration regimes. ${ }^{6}$ On the other hand, cross-region marriage within the nation state is also identified as a distinct type of marriage migration with its own set of sociological implications. ${ }^{7}$ Some scholars have suggested that globalization leads to an increase in the scale and scope of marriage-related migration. ${ }^{8}$ However, it would be incorrect to attribute increased marriage-related

\footnotetext{
${ }^{5}$ While marriages from Bengal and Africa are more correctly 'cross-region' marriages, those from Sindh are more properly 'cross-border' marriages, as they do not involve the kind of cultural adjustments that women from Bengal or Africa would have encountered.

${ }^{6}$ C. Alexander, J. Chatterji, and A. Jalais, The Bengal Diaspora: Rethinking Muslim Migration, Routledge, London and New York, 2016, pp. 131-6o; K. Charsley, Transnational Pakistani Connections: Marrying 'Back Home', Routledge: London and New York, 2013.

${ }^{7}$ R. Kaur, 'Across-Region Marriages: Poverty, Female Migration and the Sex Ratio', Economic and Political Weekly, vol. 39 (25), 2004, pp. 2595-26o3; S. Chaudhry and T. Mohan, 'Of Marriage and Migration: Bengali and Bihari Brides in a U.P. Village', Indian Journal of Gender Studies, vol. 18 (3), 201 1, pp. 31 1-40.

${ }^{8}$ N. Constable, 'The Commodification of Intimacy: Marriage, Sex, and Reproductive Labor', Annual Review of Anthropology, vol. 38, 2009, pp. 49-64. However, technologically saturated marriage scapes do not necessarily lead to more 'modern' types of marriage; see, for example, R. Kaur, 'Surfing for Spouses: Marriage Websites and the 'New' Indian Marriage?', in Marrying in South Asia: Shifting Concepts, Changing Practices in a Globalising World, R. Kaur and R. Palriwala (eds), Orient Blackswan Pvt. Ltd, New Delhi, 2014, pp. 271-92.
} 
migration to a technologically mediated modernity alone. As with other types of migration, both internal and international, marriage migration must be located within a longer duration of mobility that allowed networks of affect and economy to flourish across borders. While there is a rich record of transnational migration in the premodern era, especially across the Indian Ocean world, studies of that period have treated migrant subjects almost exclusively as male. Engseng Ho's remarkable scholarship historicizes the concept of 'diaspora' by delinking it from modernity and contemporary iterations of globalization. However, in his work, it is Hadrami men who are mobile as scholars and Sufis; they marry local women across the Indian Ocean world: Indian, Javanese, Malay, and Chinese, the women not really agents in mobility as much as the men. ${ }^{9}$ In other work, women make brief appearances as wives, slaves, or prostitutes, ${ }^{10}$ but few historical studies focus on women migrants per se. ${ }^{11}$ In this article, I bring together instances of women's migration during the nineteenth century with more contemporary cases of marriage migration to build a case for examining longer histories of women's mobility across borders in the subcontinent, but also to trace the manner in which the state's management of marriage migration reflects deeper questions about its control over the demography of borderlands.

In accessing women who have migrated into Kutch for marriage over the past century or more, I have accessed a varied archive. For the nineteenth century, I have consulted records from the colonial archive of the Bombay Presidency held at the Maharashtra State Archives (MSA) in Mumbai. These records relate to the colonial state's attempts to regulate what they perceived as 'slave traffic' across the western Indian Ocean. Secondary sources and interviews enabled me to access marriage practices of the princely state of Kutch. I combine these with an ethnography of contemporary cross-region marriage and a reading of contemporary media texts in Kutch. By bringing

\footnotetext{
${ }^{9}$ In fact, marriage is almost the opposite of mobility, as daughters are sent 'back' as marriage migrants, to more or less close the circle of mobility. E. Ho, The Graves of Tarim: Genealogy and Mobility across the Indian Ocean, University of California Press, Berkeley, 2006.

${ }^{10}$ E. Tagliacozzo, Secret Trades, Porous Borders: Smuggling and States along a Southeast Asian Frontier, I865-1915, Yale University Press, New Haven, 2005. Women appear here primarily as those trafficked into brothels.

${ }^{11}$ A recent article discusses the emancipatory potential of emigration for Dalit women: C. Gupta “"Innocent” Victims/“Guilty” Migrants: Hindi Public Sphere, Caste and Indentured Women in Colonial North India', Modern Asian Studies, vol. 49 (5), 2015 , pp. $1345^{-77}$.
} 
these texts into dialogue with each other, I hope to be attentive to the varied configurations of power and notions of truth that have produced them. The colonial archive is as much a site of uncertainty and epistemic anxiety as the ethnographic 'field'. Reading archival sources in ethnographic mode permits a reconstruction of some of the historical and discursive conditions that generated anxieties around the nineteenth-century migration of women from Africa into Kutch.

\section{'Infiltrator' men, 'trafficked' women: the Muslim migrant and India's 'citizenship regime'}

In 2001, when I first started ethnographic research in Kutch, travelling through isolated villages in the Rann of Kutch, I frequently heard the phrase 'kalkatta bai' or 'kalkatta vari bai' (women from Kolkata, the capital city of West Bengal). 'Kalkatta' was typically a euphemism for the fact that they were from Bengal; none of the women I interviewed was actually from the city, although many were Bengali and all were Muslim. For reasons of personal security-fear of the police, who might arrest them as victims of 'forced marriages' - they are hesitant to talk about exactly where they come from. 'Kalkatta' serves as useful shorthand for the fact that they are Bengali. ${ }^{12}$

A general reluctance to be identified as Bengali and possibly from Bangladesh is not surprising. The issue of 'undocumented immigrants' from Bangladesh is a potent political potboiler in India, especially when right-wing Hindu nationalist regimes are in power. At issue is the Muslim migrant, whose demographic presence remains as contested in India today as it was during the early years following the partition. Although it has been suggested that it was in the 1980 s that India began to adopt more exclusionary citizenship measures faced with the influx of vast numbers of immigrants from Bangladesh, it is also true that India's 'citizenship regime' has been biased against Muslims, right from its inception in 1947. The current debates over who is a rightful citizen and who is not thus bear the shadow of early postpartition debates on the matter. ${ }^{13}$ As I suggest here, these debates

\footnotetext{
${ }^{12}$ This is also the case for the Bengali women migrants in Delhi discussed in M. Chaudhuri, 'Betwixt the State and Everyday Life: Identity Formation among Bengali Migrants in a Delhi Slum', in Transnational Migration and the Politics of Identity, M. Thapan (ed.), Sage Publications, New Delhi, 2005, pp. 284-311.

${ }^{13}$ In the immediate aftermath of the partition in 1947, Constituent Assembly debates already reveal an inherent bias in attempts to keep out Muslims, with Hindus
} 
also bear the marks of discourses that had begun to take shape even earlier, in the nineteenth century.

Unofficial border crossings of men are frequently reported in the local and regional newspapers in Kutch. The Border Security Force (BSF) conducts routine 'raids' in border villages to identify 'infiltrators' from both Pakistan and Bangladesh. According to police reports, Bangladeshi men seek to cross over into Pakistan, whence they attempt to emigrate to the Middle East. To avoid identification as Bengali speakers, when caught, they often claim to have lost the ability to speak, or to be mentally unstable. ${ }^{14}$ Newspapers and tabloids in English and Gujarati report these cases faithfully, even throwing in the odd element of human interest as they feed stories of the trials and tribulations of Bangladeshi men caught illegally in Kutch to an eager audience. ${ }^{15}$

When the presence of Bengali-speaking women is reported, however, it is usually from the perspective of their being 'trafficked' into Kutch by organized networks of unscrupulous agents (dalals) who 'forcibly' marry these women into Kutch and other parts of India. Yet, narratives of rescue that are built into notions of 'trafficking' do not fit easily with the demonization of the Muslim woman as it plays out in the present case. I suggest that 'trafficking' in this context is taken recourse to, in order to build a case of illegality even as its content is reconfigured from early concerns of 'rescue' in the nineteenth century, to moral panics about the fear of Muslim women's sexuality in the present. ${ }^{16}$

regarded as 'natural' citizens. See N. J Gopal, Citizenship and Its Discontents: An Indian History, Permanent Black, New Delhi, 2013, Chapter 2.

${ }^{14}$ See, for example, http://articles.timesofindia.indiatimes.com/201 1-05-02/rajkot/ 29495481_1_bangladeshis-kutch-interrogation, accessed 13 April 2018; http:// archive.indianexpress.com/news/arrested-bangla-nationals-wanted-to-go-to-pakistan -via-kutch-cops/1 106907/o, accessed 13 April 2018; http://zeenews.india.com/news/ nation/three-bangladeshis-apprehended-from-border-near-kutch-by-bsf_6773o6.

html, accessed 13 April 2018; http://www.rediff.com/news/report/exfil/20070221. htm, accessed 13 April 2018.

${ }^{15}$ See, for example, http://www.dnaindia.com/india/report-cupid-struckbangladeshi-languishes-in-kutch-jail-1 273522, accessed 13 April 2018.

${ }^{16}$ Women's mobility for sex work has for a long time been termed 'trafficking' due to a long-standing moralizing tendency to collapse prostitution with trafficking, thereby not only ignoring other instances of exploitation and potential trafficking of women in factories and domestic work, but also assuming that sex work is 'immoral' and that, as such, no woman would willingly choose sex work as a form of labour. See C. Vance, 'Thinking Trafficking, Thinking Sex', GLQ: A Journal of Lesbian and Gay Studies, vol. 17 (1), 2011, pp. 135-43; K. Kempadoo, 'Abolitionism, Criminal Justice, and Transnational Feminism: Twenty-first century Perspectives on Human Trafficking', 
The media discourse about Bengali marriage migrants in Kutch draws on a general public awareness about low female sex ratios prevailing in many parts of India that have apparently led to women migrating long distances to serve local marriage needs. Yet, the reportage about Bengali women in Kutch is tinged with another fear: that of cultural contagion by the Muslim, especially a potentially childbearing Muslim woman, into the region. Thus, reports speak of 'A sea change in its [Kutch's] demographic profile. Hundreds of Bengalispeaking Muslim women are being trafficked from Bengal and Bangladesh to Kutch, where they are sold off as brides'. ${ }^{17}$

It is emphasized that 'once they bear kids [sic], most of them are disposed of or offered for sale at a higher price'. ${ }^{18}$ The concern with reproduction is evident; if continued unchecked, these marriages threaten to subvert an unwritten code in the development of India's citizenship regime from the time of partition which rendered migrating Muslims' claims to Indian citizenship, property, or belonging as somehow more outrageous than that of their Hindu counterparts. ${ }^{19}$

The theme of the Bangladeshi 'infiltrator' in India should be read against the background of citizenship debates in India and the progressive narrowing of the legal definition of citizenship. As Jayal argues, 'with the passage of time, citizenship laws are increasingly rather than decreasingly informed by the divisive legacy of the Partition'. ${ }^{20}$ In early 2014, while campaigning in the north-eastern

in Trafficking and Prostitution Reconsidered: New Perspectives on Migration, Sex Work and Human Rights, K. Kempadoo (ed.), Paradigm Publishers, Boulder and London, 2005, pp. vii-xxxv; G. Rubin, 'The Trouble with Trafficking: Afterthoughts on "The Traffic in Women", in Deviations: A Gayle Rubin Reader, Duke University Press, Durham and London, 201 2, pp. 66-86; S. Shah, Street Corner Secrets: Sex, Work, and Migration in the City of Mumbai, Orient Blackswan, New Delhi, 2014.

${ }^{17} \mathrm{http}$ ://indiatoday.intoday.in/story/bengali-speaking-girls-human-traffickingkutch-flesh-trade/1/213428.html, accessed 13 April 2018, emphasis added.

${ }^{18} \mathrm{http}: / /$ timesofindia.indiatimes.com/city/ahmedabad/Forced-brides-Kutchipeople-explore-new-matchmaking-options/articleshow/45737720.cms, accessed 13 April 2018.

${ }^{19}$ Jayal argues that, although not explicitly written as such, the debates within and outside of the Constituent Assembly clearly indicated some partiality towards the more restrictive principle of jus sanguinis (blood-based descent) over the officially espoused citizenship criterion of jus soli (birth). Heated debates over what eventually became Articles 6 and 7 of the Constitution reveal that 'the question of citizenship remained deeply imbricated in religion .... Discouraging the putative (Muslim) citizen from returning was thus a dominant theme in the formulation of Article 7', Citizenship and Its Discontents, p. 61.

${ }^{20}$ Ibid., p. 14 . 
border state of Assam, the prime-ministerial candidate appealed for the 'accommodation' of Hindu migrants from Bangladesh:

We have a responsibility toward Hindus who are harassed and suffer in other countries. ... India is the only place for them ... since a large number of Hindus are also being evicted from Bangladesh, their burden will have to be shared by all states .... The infiltrators, on the other hand, have to go. They will have to be sent back to where they came from..$^{21}$

In a speech in West Bengal, he clarified further:

Two types of people have come from Bangladesh-the refugees who have been thrown out in the name of religion and the infiltrators .... Those who are thrown out of Bangladesh, those who observe Durgastami ..., they are all our Mother India's children. ${ }^{22}$

A distinction is posited between 'migrants' and 'infiltrators' from Bangladesh, ${ }^{23}$ as, in another period, a distinction was drawn between 'migrants' and 'refugees'. ${ }^{24}$ The nature of this distinction hinges on religion: Hindus supposedly had a 'natural' affinity with India that enabled a prior claim on citizenship and belonging, while Muslimsor in this case those who do not worship the goddess Durga-are 'infiltrators' who ought to be sent back. Bengali Muslim women marriage migrants into Kutch, on the other hand, are portrayed as 'trafficked' rather than as active 'infiltrators'. This reflects a more general gender bias in the construction of migrants, where the male migrant is more likely to be viewed as a vagrant or threat to the safety of the host society, while women tend to be constructed as 'victims'. However, as I argue in this case, the portrayal of the woman as 'trafficked' does not carry with it an agenda of 'rescuing' her as much as it bears the marks of moral panics relating to the entry of childbearing Muslim women from Bengal into the region and its possible consequences, as it is perceived, for tilting the balance of population in favour of Muslims. As we shall see later on, the

${ }^{21}$ The Indian Express, New Delhi, 23 February 2014, http://indianexpress.com/ article/india/politics/narendra-modi-dares-china-asks-it-to-give-up-expansionistplans/, accessed 13 April 2018, emphasis added.

${ }^{22}$ The Indian Express, New Delhi, 4 May 2014, http://indianexpress.com/ article/india/politics/bangladeshi-infiltrators-must-go-back-refugees-welcome-saynarendra-modi/, accessed 13 April 2018 , emphasis added.

${ }^{23}$ As van Schendel argues in The Bengal Borderland, p. 198, the contemporary language of infiltration goes back to the 1940 s and $195^{\circ}$ s when it was developed to deny citizenship and land rights to immigrants coming in from East Pakistan.

${ }^{24}$ Jayal, Citizenship and Its Discontents, p. 62. 
discriminatory discourse on Muslims as 'traffickers' and 'dealers' of women (and at the time, 'slaves') does not owe its origins only to partition-era discourses; it can be traced back to the nineteenthcentury colonial state's discourse on 'slave trafficking'.

\section{Marriage and migration in Kutch}

\section{Bengali 'marriage migrants'}

Bengali migration in India has not only been critical to contemporary iterations of debates on citizenship and tabloid journalism; it has also infused the academic discussions on marriage migration within India. These marriages that take place through the intermediation of brokers with cash payments to the bride's family, across caste, region, and even religious boundaries, have been regarded as a sociologically new and relevant type of marriage and termed 'cross-region marriage' necessitated due to a 'shortage' of local women available to marry due to skewed sex ratios as a result of sex selection combined with poverty in 'sending' areas so that families send 'surplus' daughters out as marriage migrants. Studies on rural Haryana, ${ }^{25}$ eastern Uttar Pradesh, ${ }^{26}$ and north-central Uttar Pradesh ${ }^{27}$ conclude that women migrate from areas where they are available in large numbers and too poor to meet local demands for dowry, into areas that have a deficit of women due to sex-selective births. This has, they argue, facilitated the emergence of a 'marriage market' of sorts where women are matched as brides for men from these areas with a female 'deficit'. Monetary transactions involve a range of payments: to the bride's parents and various forms of cash payments given to intermediaries who may be involved in the process; wedding expenses are typically borne by the groom's family. The 'transactional' element to the exchange has raised questions over whether or not this is 'trafficking'28 but most ethnographic studies have now concluded that these marriages must not be conflated with the 'trafficking' of women and should be

${ }^{25}$ R. Kaur, ‘Across-Region Marriages', pp. 2595-6o3; P. Mishra, 'Sex Ratios, CrossRegion Marriages and the Challenge to Caste Endogamy in Haryana', Economic and Political Weekly, vol. $4^{8}$ (35), 2013, pp. 70-8.

${ }^{26}$ Blanchet, 'Bangladeshi Girls Sold as Wives'.

${ }^{27}$ Chaudhry and Mohan, 'Of Marriage and Migration'.

${ }^{28}$ Blanchet, 'Bangladeshi Girls Sold as Wives'. 
studied as a sociological phenomenon in their own right, ${ }^{29}$ as particular instances of socially sanctioned non-endogamous, inter-caste marriage among Hindus. ${ }^{30}$

Within this body of literature, it is also suggested that 'long-distance' marriage migration in India is a primarily Bengali phenomenonconstituting a 'Bengali bridal diaspora'." Elsewhere, a 'bridal diaspora' has been identified for instance in the case of Filipina marriage migrants to the United States who 'navigate their newfound dual identities as Filipina bride and American resident as a strategy to straddle two worlds, both of which they legitimately claim as their "home". ${ }^{32}$ One of the questions that the presence of 'Bengali' marriage migrants in the borderlands of Kutch raises is the extent to which the concept of 'diaspora' applies to an identity that is not acknowledged as a public or collective identity by the migrants themselves but is almost entirely ascribed to them by others. Due to the particular contexts laid out above, of the spectres of suspicion that doggedly pursue the Bengali Muslim woman in Kutch (as potential Bangladeshis, illegal border crossers, 'trafficked' women, etc.), it is extremely difficult for them to acknowledge this identity in a public way. In most of the cases I came across, acceptance into their affinal homes was predicated on a public effacement or disavowal of their prior identities, whether Bengali or otherwise; it would thus be counter-productive to attribute 'origins' to them. Doing so would necessarily replicate the policing of the 'Bengali' migrant by the anthropologist in much the same vein as is achieved by the police and the media who end up erasing many details of migrant wives in the region and reducing them to the shorthand 'Bengali' (and often by assumption, Bangladeshi).

I suggest that the presence of the Bengali woman migrant in Kutch is significant not just for a documentation of cross-region marriage migration, nor is it a particularly new phenomenon since men and

\footnotetext{
${ }^{29}$ Chaudhry and Mohan, 'Of Marriage and Migration'; R. Kaur, 'Marriage and Migration: Citizenship and Marital Experience in Cross-Border Marriages between Uttar Pradesh, West Bengal and Bangladesh', Economic and Political Weekly, vol. XLVII (43), 2012 , pp. 78-89.

${ }^{30}$ Mishra, 'Sex Ratios'.

${ }^{31}$ R. Kaur, 'Bengali Bridal Diaspora: Marriage as a Livelihood Strategy', Economic and Political Weekly, vol. XIV (5), 2010, pp. 16-18.

${ }^{32}$ T. C. Del Rosario, 'Bridal Diaspora: Migration and Marriage among Filipino Women', in Marriage, Migration and Gender, R. P. and P. Uberoi (eds), Sage Publications, New Delhi, 2008, pp. 80-1.
} 
women have been crossing borders to forge familial ties for a while in this region. The designation of the Bengali woman as an object of policing allows us to compare these different types of migration both from the point of view of what makes them 'work' (or not) as a viable form of marriage within the family/community as well as the state.

Contemporary marriage migrants from Bengal in Kutch tend to belie the narratives of 'trafficking' and 'rescue' that usually frame the migration of single women. My fieldwork among a number of Bengali wives in Kutch reveals that the terms in which their marriages are referred to are no different from any traditional arranged marriage in South Asia, at least in terms of women's choice in assenting to the marriage partner and destination. If anything, these marriage migrants are very active facilitators in the marriages-if not their own, then they certainly help set up subsequent marriages for their sisters and other members of their natal village community. Although dalals (agents) are frequently involved, these are often women who work in the familial context of marriage brokers common across South Asia. One of my acquaintances in Bhuj related that she had once accompanied an older relative to 'select' a wife for the latter's son; they went to a local woman's home, where they were presented with three or four Bengali women from amongst whom they were asked to choose. The woman's family was paid about Rs 15 ,ooo-20,000 ${ }^{33}$ (in 2013), with the dalal taking a cut. Despite this overtly transactional element to the marriage discussions, the general terms in which these marriages were described do not match the parameters of 'trafficking' that assume some degree of coercion and exploitation and/or sequential sale of women. Frequently, the dalal in media reports is a Muslim, allegedly Bangladeshi man, further fuelling public anxiety around the figure of the 'trafficker' as an unsavoury social type, moreover who is external to the local social context. In a subsequent section, I will demonstrate how this partiality for Muslims as 'traffickers' of women in the region goes back to nineteenth-century discourses on the African slave trade and the so-called 'Islamic' nature of 'domestic slavery'.

Yasmin $^{34}$ is one of seven sisters from Bengal, all of whom were married within pastoral settlements in Banni. Their husbands belonged to discrete endogamous groups that would not ordinarily

\footnotetext{
${ }^{33}$ Rates were higher for fair-complexioned women.

${ }^{34}$ All names from interviews are pseudonyms.
} 
intermarry. While acknowledging that it was difficult being in a new cultural environment, Yasmin affirmed that it was Allah who found one's life partner and there was no choice but to go wherever destiny took her. Sameena talked of the pain of being far from her parents' home-a three-day journey by train from Bhuj-and of how she regrets not being able to go to the funeral when her mother died, but she also added: 'wherever one's naseeb (destiny) takes one, one must go (jiska naseeb jahan, vahan jaana padta hai).' She described a banality to the connection between Bhuj and her village in Bengal: 'There was a time when none of us would have heard of Bhuj; now the name is on everyone's lips: it has become an everyday affair (dal-chawal jaise ho gaya hai).' Sameena took pains to underscore that her village was dehat (backward, rural, unsophisticated). Her children do not do well there; this, in addition to the time and expense involved in travel, is a disincentive to make frequent trips back to Bengal:

The conditions there (hawa-pani) don't suit the children; although everyone there is related to them (unke apne hain), they cannot relate to anybody. They don't speak Bangla as I can't speak it with them here. They always get sick there. The last time I travelled with them, they were sick so we left to return early. Once we reached Bhuj, we had no need to even get medicines from the doctor; they recovered spontaneously.

She emphasized again that, although her village was dehat, people were very greedy and demanded high dowries, unlike in Kutch, where people were simple yet open-hearted:

People are very poor and it is backward (dehat). Yet, they demand lakhs (one hundred thousand) of rupees in dowry. They want a lot of things. Here in Kutch, among [she names her husband's community], even if they are a wellto-do family, they will sit on the floor and eat. In my village, they want tables and chairs and whatnot. They bathe out in the open river like animals, but then they want fancy things in marriage.

Typically, the women I interviewed travelled to Kutch at the time of or just before the marriage. They were accompanied by a family member, often their father, or dalals who fixed the marriage. Bano described how her husband was unusual, for he came in person to her village and 'hid nothing from us'. He was very unwell and needed palliative care. He had a wife whom he had not divorced, but who was 'mentally unstable' (dimagi haalat theek nahi hai). Bano added: 'the entire village knows (saara gaon jaanta hai) that I have come for his care (seva). There is nothing wrong in this.' She also admits to facilitating 
two marriages, one of them for her neighbour's son. The young woman is from her own village and now they plan their trips home together so they can have each other's company on the long train journey. Another marriage she helped set up was for her sister. Apart from dalals, who charge standard rates and commissions, dealing with multiple women at a time, married women from Bengal also become facilitators for this kind of migration once they themselves have moved to Kutch. Their advantage is in knowing the place and people first hand, and they do not charge a fee: money is paid directly to the woman's family. On one of the occasions that I was at her home, Bano was expecting a prospective 'client' from Bengal:

They must be on their way here. A family from [a neighbouring village] was interested, so I arranged the meeting, which will take place in my house this evening. They have said if they like the girl, they will take her and pay, but not otherwise. I told them, that's fine; after all, we are hardly dalals to strike a deal.

While I did meet some women who were unhappy (dukhi) as they were 'duped' into marrying men who were not as well-off as they had been led to believe, their distress was not due to the fact of migration from Bengal, nor was it to do with the fact that they had been tricked into migration under pretexts other than marriage. While she knew she was to marry, the true details of her husband had been concealed from Akbari. Her husband turned out to not be the industrial worker she was promised, but a daily wage labourer eking out a living that barely sustained the two of them. She tried to supplement their meagre income by tying cloth that is outsourced to her as a prelude to the tieand-dye method for producing coloured cloth locally known as bandhani. The work was erratic, not very highly paying, and hard on her eyes. They lived in a small tent pitched behind a mosque in conditions of such squalor as have only come to be seen after the earthquake of 2001 when urbanization and haphazard town planning have given rise to urban poverty of a kind virtually unknown in Kutch earlier. Their home used to be a one-roomed structure that they rented from the mosque, but it came down in the earthquake and, when it was rebuilt, they were displaced. Akbari said: 'my entire life has been destroyed by that man (the dalal). I curse him for ruining my life; he has killed me, now he should die a painful death.' When asked whether complaining about him to the police might help her to be repatriated to Bengal, she was equally clear that going back was not an option. 
Although brides from Bengal have acquired recent visibility in Kutch, and as their networks grow, they are able to arrange more marriages for their kinswomen in Kutch, it is important to situate these marriages within the larger landscape of marriage and migration in Kutch. Migration for marriage in Kutch is not new or considered to only be a poor substitute for a local match. The Jadejas, former rulers of Kutch who hailed originally from Sindh, usually married Sodha women from across the border. The princely state of Kutch received brides from Sindh, and in some cases from other princely states in the region such as Kathiawar or the states of Rajasthan. ${ }^{35}$ It has been argued that strict clan exogamy combined with firmly enforced hypergamy made Jadeja daughters 'dispensable'-they could not marry within the Jadeja fraternity, yet could not marry anybody lower in statuswhich effectively meant that they could not marry in Kutch. This has been taken to mean that they 'practised wholesale female infanticide, until they were most rigorously dissuaded'. ${ }^{36}$

However, this argument gives too much credit to the British for 'dissuading' the Jadejas from a cultural practice, and too little credit to the Jadejas for inventing alternate marriage strategies for their daughters. As Frances Plunkett has argued, hypergamy does not always proceed hand in glove with infanticide. Theoretically, at the top rung of a hypergamous chain, daughters cannot be married honourably. However, in practice, daughters were often exchanged between royal houses of equal status, as happened for instance between the rulers of Sirohi and Kutch. Further, we know that, while daughters could not marry 'down', rulers had no compunctions in making marriage alliances with women from less prestigious lineages, slaves, or concubines. Further, 'infanticide' was not an allencompassing category either; daughters born to Jadejas of official wives were more likely to be killed at birth than those born of slave mothers. It is suggested that slave-born daughters could be used to meet political goals through marriage, while those born to official

\footnotetext{
${ }^{35}$ The uncle of the last crowned Maharao, whom I last interviewed in 2003, had a wife from Kathiawar; the Rao of Sirohi (1925-46) married a daughter of the Maharao of Kutch, while the Kutch ruler married the Rao of Sirohi's sister; F. Plunkett, 'Royal Marriages in Rajasthan', Contributions to Indian Sociology, vol. 7 (1), 1973 , p. 72.

${ }^{36}$ A. Clark, 'Limitations on Female Life Chances in Rural Central Gujarat', Indian Economic and Social History Review, vol. 20 (1), 1983, p. 15 .
} 
wives were more likely to be killed due to the higher cost of maintaining them. ${ }^{37}$ Slave daughters did not have the compulsions of hypergamy and large dowries attached to them and could be used politically. Thus, we must pay attention to strategies of selection both of sex and marriage. The acknowledgement of female infanticide at a particular moment does not differentiate between those daughters who could be killed and those who could be used as political capital to further political goals; it was important to identify which ones could be used as royal currency by sending them away in marriage and which ones were not thus valued. Even as some Jadeja daughters were sent away in marriage and used to further political goals of alliance, their wives were typically sourced from the Sodhas of the Thar. Marriage practices among the Jadejas thus necessarily implied some border crossing. The border between TharParkar in Sindh and Kutch was frequently traversed, as these marriage alliances were sealed throughout the period of Jadeja rule. Of greater significance after 1947, in terms of volume, are the marriages of border communities across the KutchSindh border. These marriages continued unabated until 1965 , when the border became more rigidly policed in the aftermath of a war with Pakistan. A number of Hindus, especially Sodhas and lower castes such as Meghwals, remained in Sindh, as they had not crossed over at the time of partition. Some of them continued to seek marriage partners across the border in Kutch and Rajasthan.

Unlike the Bengali women, who are able to return to their natal villages to visit, women from Sindh are unable to return, as they lack formal travel documents and authorizations. ${ }^{38}$ As they are without visas, or with long-expired ones, they are unable to identify themselves

${ }^{37}$ I. Chatterjee, 'Introduction' in Unfamiliar Relations: Family and History in South Asia, I. Chatterjee (ed.), Permanent Black, New Delhi, 2004, pp. 12-13.

${ }^{38}$ The nature of the Bengal and Sindh borderlands is quite different; thus, even women who are technically from Bangladesh are able to travel back home. Partition did not seal off the Eastern border as definitively as it did the Western one. Agricultural labour, weekly markets, and marriage networks all involve continuous crossing of the border between West Bengal and Bangladesh, sometimes on a daily basis; W. van Schendel, 'Working through Partition: Making a Living in the Bengal Borderlands', International Review of Social History, vol. 46, 2001, pp. 393-421; J. Cons, 'Histories of Belonging(s): Narrating Territory, Possession, and Dispossession at the IndiaBangladesh Border', Modern Asian Studies, vol. $4^{6}$ (3), 201 2, pp. 527-58. Marriage networks had always linked the two Bengals and, after partition, it was these networks that enabled East Bengalis to migrate to the West. Since East Bengali men tended not to migrate for work, these affinal networks became the central nodes of migration patterns to the West, upsetting long-entrenched patrilocal, patrilineal settlement patterns and giving women's status a boost, as her marital home could become a 
and prefer to live somewhat undetected lives. As they share cultural similarities with their host communities, it is easier for them to blend in. Unlike their male relatives from Sindh, who are more readily arrested as 'infiltrators', especially if they are Muslim, marriage tends to be protective of the status of women who have crossed from Sindh; even if they lack the benefits of citizenship, their status as married women secures them against the stigma of being 'trafficked', regardless of their religion.

These selective settlement patterns adopted by the state, apart from being discriminatory and inattentive to the contexts of cross-border marriages, reveal the moral panics that have come to bear on the figure of the Muslim in general, but more specifically the 'Bangladeshi' Muslim, who becomes, in the present, the chief threat to carefully laid settlement plans that sought to clearly distinguish India's borders from its Muslim-majority neighbours.

\section{Kutch-Africa marriages ${ }^{39}$ : the 'trade in slaves', and 'Islamic' slavery}

Throughout the nineteenth century, there was another category of cross-region marriage in Kutch. Merchants from the princely state of Kutch travelled across the seas to trade in Muscat and Zanzibar. Hindu Bhatias and Muslim Khojas and Memons were part of this thriving network of trade that constituted the economy and cultural life of the western Indian Ocean. ${ }^{40}$ By 1811 , it is estimated that "nearly $5^{\text {o per }}$ cent of the imports at Zanzibar consisted of "Surat cloths" from Kutch and Surat'. ${ }^{41}$ During this period:

Indian trade with East Africa was dominated by Kutch, and to a lesser extent Gujarat, which explains the cultural dominance of these regions over the Indian merchant class at Zanzibar ever since .... The 'Swally' trade, as the

refuge for her natal relatives; J. Chatterji, The Spoils of Partition: Bengal and India, 1947-1967, Cambridge University Press, Cambridge, 2007, pp. 124-6.

${ }^{3}$ I subsume under this a range of intimate relationships that were forged between men of Kutch and African women, even though I am aware of the fact that not all of these relationships were necessarily 'marriages' in the legal sense of the term, nor that 'marriage' itself is necessarily the most appropriate term for the entire set of relationships that it usually seeks to contain. See I. Chatterjee, Gender, Slavery and Law in Colonial India, Oxford University Press, New Delhi, 1999.

${ }^{40}$ For a meticulous account of the Kutchi merchant diaspora across the western Indian ocean, see C. Goswami, The Call of the Sea: Kachchhi Traders in Muscat and Zanzibar, c. I80o- I880, Orient Blackswan Pvt. Ltd, Hyderabad, 2011.

${ }^{41}$ A. Sheriff, Slaves, Spices and Ivory in Zanzibar, James Currey Ltd, London, 1990, p. 84 . 
trade with East Africa was called, (from Sawahil, the coast), came to dominate the foreign trade of Kutch. Whereas in 1818 the trade was mentioned without any superlatives, by 1833 it was described as 'the most valuable branch' in which up to twenty vessels from the main port of Mandvi were involved. ${ }^{42}$

The economic connections between these regions had a corresponding cultural and familial universe that came into being through centuries of contact. Narratives of slave women, who are the subjects of this section, are not presented here to posit a seamless comparison with the moral panics and demographic anxieties that relate to the contemporary phenomenon that has been termed 'marriage migration' and discussed in previous sections. I bring together these different types of border crossing and how they are received, to gesture towards the larger point about regimes of surveillance with regards to the mobility of women which clearly has a longer history than the contemporary moral panics about cross-region marriage migration in Kutch would suggest. Discourses of marriage and trafficking were central to the ways in which the colonial police department in Bombay, through consultations with political agents across the region, determined the legality of the women they found on board ships, and accordingly determined their future course of action with respect to them: whether they were to be 'repatriated', 'rescued', or 'settled'.

In the nineteenth century, the British administered large parts of India directly, and had friendly relations with the rulers of Kutch, Oman, and Zanzibar; these relations nevertheless came under significant pressure over the question of the slave trade and its abolition. This was not an easily resolved question however, with even different British political agents adopting various positions on the slave trade. On the one hand was the view that the traffic in and the possession of slaves was a criminal offence, such as the observation made by Henry Churchill, Political Agent and Consul at Zanzibar in a letter to Sayid Majid, the Sultan of Zanzibar in 1867: The act of bringing, settling, and possessing slaves is, according to the criminal laws of India, a crime punishable in a manner less severe than murder, but more so than theft, and it is a crime that it behooves me to punish whenever it is committed by a British subject. ${ }^{43}$

${ }^{42}$ Ibid.

${ }^{43}$ MSA, Political Department, 1 868, Vol. 135, 'Zanzibar Slave Trade', File No. 478, 'Regarding the Abuse of British Laws for the Suppression of the Slave Trade by Her Majesty's Indian Subjects Established in the Dominions of the Sultan of Zanzibar'. 
On the other hand were those political Agents who argued that the structure of slavery was embedded into the very structure of the Indian family and should be treated as a different form from the Atlantic model of slavery known to the West. Thus, some of the records speak of the 'mild' nature of slavery and make much of the fact that they were integrated into the household structure. Goswami observes that colonial records 'state that the treatment the slaves received was of the "kindest" nature and they appeared to be treated more as members of the family to which they belonged than as "menials". ${ }^{44}$ These records mentioned those slaves who simply were unwilling to be set free ${ }^{11}$ or those whose enslavement was presumed to be 'of perfect free will'. ${ }^{45}$ In fact, commenting on the inevitability of the movement in slaves, and the difficulty of taking a firm stand on the so-called traffic in slaves, Major Hamerton, the Consul and British Agent in Muscat wrote to the Bombay government in $185^{\mathrm{o}},{ }^{46}$

There is not a Banian or an Indian Mussulman who has resided for any length of time in any part of the Imam's dominions who has not purchased African females with whom they cohabit during their stay in the Imam's countries and when they leave they generally make them over, or sell them to a friend. The Banians never bring their wives with them to the Imams dominions either in Arabia or Africa nor do they take the women they get here away with them when they leave for their own country; but the Indian Mohammedans frequently do, particularly when they have had any family by them. They are fond of the children and generally make a nikkah with the mother. ${ }^{47}$

While the Bombay Presidency was under British administration, subjects of the Rao of Kutch were not British subjects in the strict sense of the term. The involvement of Kutchi traders in the trade in slaves, although acknowledged as a fact by the colonial authorities, proved to be harder to clamp down on than they thought, as the slave owners and dealers exercised their rights as subjects of competing administrative dominions as and when it suited them. ${ }^{48}$

${ }^{44}$ C. Goswami, The Call of the Sea: Kachchhi Traders in Muscat and Zanzibar, c. I8ooI 880, Orient Blackswan, New Delhi, 201 1, p. 244.

${ }^{45}$ For example, MSA Political Department, 1857 , Vol. 131, File No. 453, 'Relative to the Adoption of Measures for Preventing the Traffic in Slaves between Zanzibar and Kutch'.

${ }^{46}$ Political Resident of Kutch in 1832, quoted in Goswami (201 1: 244).

${ }^{47}$ MSA, Political Department, 185 o, Vol. 153, File No. 1101 , 'Regarding the Purchase of a Seedee Female at Muskat by a Native of Kutch'.

${ }^{48}$ A Political Consultation of 1868 asked pertinently: 'Slaves to the extent of 1200 are held in Zanzibar by natives of India, who although not HM's subjects may yet be under the jurisdiction of the British Government. The persons in this anomalous 
The second difficulty faced by the British authorities in their campaign against the slave trade was the problem of 'slave women' and their so-called 'dealers' who refused the state's identification of them as such, or who refused to be 'rescued' and 'rehabilitated' as trafficked slave women. In the $185^{\text {os }}$ and 1860 s, a number of women found on board ships sailing between the western coast of India and Africa were captured by the authorities on the suspicion of being slaves. They were sent to the presidency government in Bombay for further action. Marriage was used as a protective institution once again, as a number of times it was claimed that, because they were legally married to the men they accompanied, who were not slaves, per Islamic law, they were free women and not liable for repatriation. Some even produced marriage certificates in support of their claims, in which format the documentary state was more likely to accept their statements. ${ }^{49}$ Regardless of whether the women agreed with their deemed 'captors', marriage or motherhood was often invoked to avoid the stigma of being a 'slave'. ${ }^{50}$ Men also often as not claimed they were not slaves as suspected and asked to be sent back to their

position are the subjects of the Rao of Kutch. Hitherto the privileges only of these persons have come under consideration; and it has been held that as the Rao of Kutch has no external relations, his subjects in foreign countries are morally entitled to all the privileges enjoyed by natives of British India in the same places. But now has arisen a question not of their privileges but of their liabilities. May the natives of Kutch hold slaves, and thereby commit what would be an offence against British laws if committed by natives of British India?', MSA, Political Department, 1868, Vol. 135 , 'Zanzibar Slave Trade', File No. 478, 'Regarding the Abuse of British Laws for the Suppression of the Slave Trade by Her Majesty's Indian Subjects Established in the Dominions of the Sultan of Zanzibar'.

${ }^{49}$ In 1860 , the Fateh-ul-Khair was apprehended by the British on suspicions of its being a slaver. A woman was found on board and-it being assumed that she was a slave-was taken into custody. She was identified as Hasina, an Abyssinian woman bought as a slave by the ship's nacoda (captain), Haji Ahmed Ali, at the port of Hodeida in Yemen for 70 dollars. Much later, upon direct examination, Hasina denied the marriage, stating that she wished to remain with her present husband, whose child she was carrying at the time. MSA, Political Department, Vol. 105, Persian Gulf, File No. 349, 'Relative to the Captured Slaver "Futteh-el-Khair" with a Female Slave'.

${ }^{50}$ See, for example, Farasho's statement, taken in Muscat, 1860: 'My name is Farasho daughter of Salmeen. I was sold last Suffer (September 1859) by Khodaida walad Yousif, a Biloochee, to Solaiman, a native of Kutch. He kept me as his Concubine, and in the course of time I became pregnant. Seven months ago, he got sick, and died. A relative of his, named Kadoo, took possession of all the property of my late Master, and he only gave me enough to live upon. Two months after, Mohammed Ali (Defendant) brother of my late Master, arrived from Kutch, and took possession of all my late Master's property, and two months after that I was delivered of a son. I knew that I was then a free woman according to the Mohammedan law' (emphasis added). MSA, Political Department, 186o, Vol. 95, File No. 48 (Secret), 'Report on 
ports of embarkation. The authorities admitted that it was evidently impossible to do anything respecting the manumission of men who either were not slaves, or were unwilling to be set free'. ${ }^{51}$

As the power of the state grew in the post-186o period, the crux of the matter in political terms for the British was to establish their relative authority vis-à-vis the Sultan of Zanzibar over the control of the Kutchi merchant diaspora there who was said to constitute 'the wealthiest class of the trading population of Zanzibar' ${ }^{52}$ By their own admission, the question was a complicated one because, if they were to come down too heavily on the slave trade, penalizing these merchants, the latter might choose the jurisdiction of the Sultan over the British-something they had already begun to do. The British argued that

while the natives of Kutch established at Zanzibar, were under our sole protection and jurisdiction, we held the most wealthy and enterprising among the mercantile community and our influence was in all matters paramount. ${ }^{53}$

This happy state of affairs ended when subjects of Kutch were offered British protection only if they registered their names at the Consulate in Zanzibar. Many did not. This allowed them to use their ambiguous subject position to escape the application of Britain's anti-slavery laws, as the law in Zanzibar allowed them to deal in slaves. ${ }^{54}$

Faced with the imminent loss of their loyal-and wealthyconstituents in Zanzibar, the British decided to permit 'domestic slavery', which would be restricted to a few slaves-not more than one or two per family_and to prosecute the commercial buying and

the Circumstances of a Suspicious Case of Slavery against a Native of Kutch and Resident at Muscat'.

${ }^{51}$ MSA, Political Department, 1857, Vol. 131, File No. 453, 'Relative to the Adoption of Measures for Preventing the Traffic in Slaves between Zanzibar and Kutch'.

${ }^{52}$ MSA, Political Department, 1868, Vol. 135, File No. 478, 'Regarding the Abuse of British Laws for the Suppression of the Slave Trade by Her Majesty's Indian Subjects Established in the Dominions of the Sultan of Zanzibar'.

${ }^{53}$ MSA, Political Department, 1869, Vol. 152 , File No. 121 , 'On the Subject of the Traffic in Slaves by Kutchees in Zanzibar'.

54 'Afterwards, as a settlement of certain vexed questions connected with the slave trade, each Kutchee was allowed to elect his protecting State, and HH [the Sultan of Zanzibar] by holding forward the Arab privileges of buying and selling slaves, ... secured every new arrival from Kutch to himself, and confidently looked forward to the time when British influence would be reduced to an equality with that of France and other foreign powers having no material stake in the country. During the past four years registrations at the British Agency, have become almost unknown', ibid. 
selling of slaves, or 'slave dealing'. Kutchi merchants could legally remain 'slave owners' but not 'slave dealers'. ${ }^{55}$

In allowing 'domestic slavery' as legal practice, the British were differentiating between 'domestic' or 'familial' slavery as distinct from the 'economic' slavery that had in their view characterized transAtlantic slavery. 'Domestic' slavery further became intertwined for the British, with notions about how Muslims ran their family structures. This in turn was to have enduring consequences in India. It has been pointed out in the context of trans-Saharan slavery that the twin discourses of Abolitionism and Orientalism came together to produce 'Islamic slavery' as a special type of domestic slavery involving women and children as unique to Muslim Africa. ${ }^{56}$

This was to have repercussions for the discourse on slave trade in India as well. So-called 'domestic slavery', now permissible to the merchants of Kutch, implied the incorporation of African women into the family, and was seen as a trait peculiar to Muslims of Kutch more so than to Hindu merchants. As the British resident in the Persian Gulf wrote in 1847 :

The custom of slavery, and of buying and selling Africans and Abyssinians, is so interwoven in all the religious and social habits of the Mahomedans, that years must elapse before they can be brought to look upon so doing in the same iniquitous light that we are accustomed to view it. ${ }^{57}$

Further, it was assumed that Hindus from Kutch involved in the trade were more amenable to being dissuaded by the government and that they 'would willingly abandon it, if a written engagement to that effect

\footnotetext{
55 'All traders or others, subjects of the Rao, who are proceeding to Zanzibar, or who are actually residing there, should be warned that though mere domestic slavery by Kutchees may be tolerated for the present, the British Government will take steps to interfere with any prosecution of the traffic in human beings and that no claims for loss or compensation, in the event of the release of any number of captives, sold or being hurried into slavery, will be tolerated for a moment'. MSA, Political Department, 1868, Vol. 135, File No. 478, 'Regarding the Abuse of British Laws for the Suppression of the Slave Trade by Her Majesty's Indian Subjects Established in the Dominions of the Sultan of Zanzibar'.

${ }^{56}$ E. A. McDougall, 'Discourse and Distortion: Critical Reflections on Studying the Saharan Slave Trade', Revue Française d'Histoire d'Outre Mer, vol. 89 (336-337), 2002, pp. $195^{-227 .}$

${ }^{57}$ MSA, Political Department, 1847 , Vol. 115 , File No. 1345, 'Number of Slaves Seized and Brought to Bombay, Disposal of Them'.
} 
were taken from them all ${ }^{58}$ and, moreover, if they were to be penalized for their actions back in Kutch. ${ }^{59}$

What lessons can we draw from the above discussion for the manner in which women's migration into Kutch has been constructed as 'forced' or 'trafficked' in the present? First, the discourse of human trafficking relative to cross-region marriages/intimacies is not new. Just as in the nineteenth century, the legal and social status of 'marriage' or 'motherhood' sometimes helped protect women from being repatriated; in contemporary times, Sindhi women are able to use cultural similarities with Kutch to avoid detection as 'outsiders' and thus the charge of 'trafficked' women. The second lesson that is relevant for this argument is a gradual consolidation of the idea that those who were involved in 'slave dealing' and the incorporation of Africans into their families were the Muslims of Kutch rather than Hindus. In assimilating 'domestic slavery' into their very cultural identity, the trafficking of slaves is more than an economic or moral ill; it is bound up with the cultural elaboration of the family itself. With the passage of time, the culprit to be held accountable and punished for slave dealing and 'trafficking' was rapidly boiling down to his religious identity.

${ }^{58}$ MSA, Political Department, 1856 , Vol. 93, File No. 335, 'Relative to the Suspected Traffic in Slaves in the Territories of His Highness the Imaum of Muscat by Banians of Kutch'.

59 'I have frequently been told that if the Banians were obliged to enter into engagements in Cutch, before coming to Zanzibar, not to engage in the slave trade, under certain penalties, that they one and all would abstain from this traffick [sic] even such men as Ebjee Sewjee, and other influential and wealthy individuals who have derived great profits from the slave trade to the southward of the Imam's territories. They have ways and means to convey slaves from the ports in the Imam's dominions to the different parts on the coast of Madagascar, where the Brazilian and Portuguese slave agents are always ready to receive them. The Banians certainly would not do this were they afraid of evil consequences to their property and persons in Cutch. ... if some measures were taken to deter the subjects of the protected states in India from entering into this traffick [sic], it would wonderfully assist $\mathrm{HH}$ the Imam in meeting the wishes of Her Majesty's Government and the people of England'. Major Atkins Hamerton, Consul and Agent at Muscat to A. Malet, Secretary to Government of Bombay, dated Zanzibar, 14 May 1853. MSA, Political Department, 1853 , Vol. 92, File No. 1028, 'Relative to the Projects of Kutch Banians Connected with the Reestablishment of the Slave Trade in His Highness the Imam's Dominions to the Southward'. 


\section{Sexuality and citizenship}

I have placed this study of marriage-related migration in a single region within a larger attempt to bring together debates on citizenship and borders with sexuality and gender. I hope that this helps construct a genealogy of the 'citizenship regime' in operation today and help us understand why some cross-region marriages are viewed with greater suspicion and fear than others. What specific fears do the migration of Bengali Muslim women into Kutch unshackle from the certainties that partition was to have settled many decades ago? How does the Bengali woman as childbearing agent threaten the cultural profile of border populations-a problem thought to have been settled soon after partition itself, in favour of a Hindu-majority India?60

Can the relative evaluation of these marriages by the state be viewed in relation to the settlement policies undertaken by the newly post-colonial state soon after 1947 , where borderlands were to be settled with the 'right' sorts of people, who would be loyal to the state? This brings the question of the state and citizenship into the domain of what is assumed to be 'private'-marriage, reproduction, and the family. The so-called 'private' space of sex and/or the family has, however, always been a concern of state authority. Sexual governance-the control of women's sexuality, conjugality, and the definition of 'marriage' and the 'family' by a patriarchal stateindicates that the state has always concerned itself with the intimate lives of its citizens. ${ }^{61}$ In this regard, it is also essential to note the continuities between contemporary iterations of the state and its

${ }^{60}$ After partition, official attempts were made to cleanse Indian districts on both the eastern and western borders of Muslims, following the perception that they were unlikely to remain loyal to India during a crisis.

${ }^{61}$ See, for example, T. Sarkar, Hindu Wife, Hindu Nation: Community, Religion, and Cultural Nationalism, Permanent Black, New Delhi, 200 1 C. Gupta, Sexuality, Obscenity, Community: Women, Muslims, and the Hindu Public in Colonial India, Permanent Black, New Delhi, 2001; Chatterjee, Gender, Slavery and Law in Colonial India; P. Mody, The Intimate State: Love-Marriage and the Law in Delhi, Routledge, New Delhi, 2008; Kapur and Cossman argue that the boundaries between the public and the private are constructed by law, for example, in its definition of legitimate and illegitimate sexuality, but this boundary is a constantly shifting one; R. Kapur and B. Cossman, Subversive Sites: Feminist Engagements with Law in India, Sage Publications, New Delhi, 1996. Also see L. Berlant, 'The Intimate Public Sphere', in The Queen of America Goes to Washington City: Essays on Sex and Citizenship, L. Berlant (ed.), Duke University Press, London and Durham, 1997, pp. 1-24. 
colonial and pre-colonial predecessors. ${ }^{62}$ I should clarify that the state is by no means the only source of sexual governance. We know from these interventions that caste, family, and community are deeply allied with an essentially patriarchal state when it comes to women's issues. ${ }^{63}$ In the case of women migrants, although law is fairly central to the manner in which the mobile woman is viewed as a counter to the figure of the normatively 'good' woman, namely one who stays at home rather than moves, ${ }^{64}$ her agency in contracting a socially acceptable marriage is also circumscribed by communities of kin, caste, and religion. ${ }^{65}$

In the Indian context, we are already familiar with the struggles to define women's chastity and conjugality as the basis for cultural nationalism. ${ }^{66}$ Charu Gupta, ${ }^{67}$ writing about the Hindi public sphere of colonial North India, has described the reconstitution of sexual moralities to ensure bourgeois respectability and high textual morality to the depiction of Hindu women whose representation consequently aspired to a 'shift from the sensual to the virtuous' ${ }^{68}$ The 'Hindu woman', thus conceived of in monolithic, upper-caste terms, was to be protected from the Muslim man, whose sexuality was portrayed as hyperactive and aggressive. The consolidation of a monolithic 'Hindu' identity was thus achieved in late-colonial India primarily by anchoring the authentic and inviolate nationalist subject in the body of the chaste, virtuous, upper-caste woman, and by demonizing the Muslim, especially the Muslim man, as the common enemy. A spate of 'abduction' stories circulated in the popular media in the 1920 s enabled the consolidation of the 'Muslim' as the chief threat to the emergent Hindu community as they targeted the Muslim man as the

${ }^{62}$ P. Uberoi, 'Introduction: Problematising Social Reform, Engaging Sexuality, Interrogating the State', in Social Reform, Sexuality and the State, P. Uberoi (ed.), Sage Publications, New Delhi, 1996, pp. ix-xxvi; U. Chakravarti, 'Wifehood, Widowhood and Adultery: Female Sexuality, Surveillance and the State in $18^{\text {th }}$ c. Maharashtra', in Uberoi, Social Reform, Sexuality and the State, pp. 3-21.

${ }^{63}$ Ibid.

${ }^{64}$ R. Kapur, Makeshift Migrants and Law: Gender, Belonging and Postcolonial Anxieties, Routledge, New Delhi, 2010.

${ }^{65}$ As P. Mody argues, even when the law permits choice-based marriage between consenting adults, the social acceptance of such marriages can lag far behind the legal framework: 'what the law allows is not the same as that to which society assents', Mody, The Intimate State, p. 144.

${ }^{66}$ Sarkar, Hindu Wife, Hindu Nation.

${ }^{67}$ Gupta, Sexuality, Obscenity, Community.

${ }^{68}$ Ibid., p. 40. 
lascivious aggressor who set out to 'abduct' the virtuous and innocent Hindu woman. ${ }^{69}$

In an interesting transformation in the present, it is the Bengali woman who is the new element of 'danger', threatening to alter the 'demographic profile' of the region by marrying Muslim men. The demonization of the Bengali woman in Kutch emerges from the conjunction of two sets of discourses that, when they are amplified through mass media effects, end up creating what Lauren Berlant has called 'paramnesias' - they erase actual memories or events and replace them with 'image traces of political experience about which people can have political feelings that link them to other citizens and to patriotism' ${ }^{70}$

The two sets of discourses are, on the one hand, the Bangladeshi 'infiltrator' as a fear-inducing category and, on the other, a deep cultural anxiety over the supposedly unbridled sexuality of Muslim women consequent upon the legal and cultural acceptance of polygamy in Islam. This relates to a long-existing-and growing-Hindu nationalist anxiety that Muslims will outnumber them due to legally permissible polygamous marriages under Muslim personal law. The Bengali woman marriage migrant thus brings together two key fears of the cultural-nationalist anxiety over the future of the nation form: the fear of the Bangladeshi 'infiltrator' and the Muslim woman as symbol of excessive sexuality.

Even as these discourses come together in the present to target the Bengali marriage migrant as unwanted and illegal, Hindu brides from Sindh are able to convert illegal border crossings into citizenship and political capital. $^{71}$

${ }^{69}$ Ibid.

${ }^{70}$ Berlant, The Queen of America, p. 57.

${ }^{71}$ Muslim brides from Sindh do not possess this capital, but neither are they the subjects of the 'trafficking' discourse. One reason for this is the cultural contiguity between Kutch and Sindh, making it easier for Sindhis to 'pass' as locals. As I have argued above, 'marriage' as a status protects them within the community. In 2003, a number of Hindu migrants from Pakistan were able to acquire Indian citizenship; in 2015 , a Home Ministry notification stated its intention 'on humanitarian considerations, to exempt Bangladeshi and Pakistani nationals belonging to minority communities ... from the relevant provisions of rules and order made under the Passport (Entry into India) Act, 1920 and the Foreigners Act, 1946, in respect of their entry and stay in India without such documents or after the expiry of those documents', Press Information Bureau, Government of India, Ministry of Home Affairs, 7 September 2015, http://pib.nic.in/newsite/PrintRelease.aspx?relid=126688, [accessed 16 April 2018], emphasis added. 
What does this selective appraisal of cross-border marriages tell us about the 'citizenship regime' the newlywed bride becomes a part of? I have suggested that the fear of 'unchecked' migration of Bengali Muslims into Kutch threatens to upset the relative balance of Hindus and Muslims in border areas, put into place after the partition. While Muslims from Thar are also unwanted by the statethey were not granted citizenship along with Hindus from Thar in 2003, nor do they come under the purview of the 2015 notificationthese border crossings, albeit illegal, are contained within a larger regional universe where there are strong cultural and historical contiguities across the border. Their marriage practices are not sociologically 'new', as they tend to marry within their old kin and community networks, even if they have to cross a border to do so. Marriage migrants from Bengal, on the other hand, are cross-region migrants, not simply cross-border ones. Too many Muslim brides from Bengal or Bangladesh, who would then bear children in Kutch, would threaten to topple the border district's demographic profile. In the late 194 os and $195^{\circ}$ s, many official plans on both the western and eastern borders attempted to create a 'loyal' buffer of Hindus and to break the preponderance of Muslims in border districts. ${ }^{72}$ The crossregion marriages of the present threaten to undo this demographic border.

\section{Conclusion}

Through a broad survey of marriage-related migration in one district over a period of time, this article suggests that marriage migration should be treated as a separate category of gendered migration. This is to say, as a special case of women's migration, it ought not to be

\footnotetext{
${ }^{72}$ Soon after partition, it was recognized that something needed to be done to Hinduise, the police force in Kutch, which had too many Muslims for a strategic district bordering West Pakistan. 'It has been admitted that Kutch is in a strategically important position and the communal composition of the Police force is deserving of attention especially in view of the fact that there is a preponderating element of Muslims in the force. It may be considered desirable to rectify this position when there is a convenient opportunity like the present when the expansion of the force could be effected by recruiting persons of the other community to make up for the lack of balance now existing', National Archives of India (NAI), Ministry of States (Secret Branch), 1948, File No. 31 (15) E. Similarly, 'in 1951, [the West Bengal] government began to "cleanse" the border zones of Muslims', Chatterji, The Spoils of Partition, p. 176 .
} 
conflated with other types of migration undertaken by women such as migration for work, including sex work, and must not be confused with issues of 'trafficking'. The fieldwork from which this article is drawn shows that often women themselves are central to networks of marriage migration as they develop over time as they facilitate other marriages. The figure of the dalal as reported in the media is usually a Muslim man, not unlike the cases of slave trading in the nineteenth century. Yet, in many of the cases studied, this role is played by the women themselves. Many of the women were motivated to migrate due to a desire to escape poverty at home (what was described to me as dehat in comparison with Kutch) or to be with a much-loved sister or other family member. In most cases, it was acknowledged that matchmaking is not in the hands of mere mortals and one has to accept one's destiny in such matters. Thus, it is problematic to read all cross-region marriages as 'forced' marriages just because they involve long-distance migration. In historicizing marriage-as structure, but also as aspirational category-over time, this article seeks to move away from the singularity of marriage as framed in the dominant sociological discourse on marriage in South Asia, which is primarily concerned with it as an endogamous structure that conforms to caste or religious boundaries. As the nineteenth-century material shows, whether the women in question were legally married to the men they were with or not, whether they were 'slaves', 'concubines', 'mistresses', or 'wives', they were inducted into the domestic lives of many merchants. Further, 'marriage' as an aspirational category often lent women protection from being 'repatriated' or 'rescued'. Many of the Bengali brides I interviewed talked of how marriage led to an escape from dehat and crippling poverty; as a socially sanctioned status, it allows women the relative freedom to move away from home. Contemporary debates on cross-border marriage migration in Kutch help in understanding the present anxieties over citizenship, sexuality, and belonging. These anxieties are brought to a head in the figure of the Bengali Muslim marriage migrant and are so widespread that all Bengali-speaking persons are tarred with the same brush and assumed to be from Bangladesh-therefore illegal 'infiltrators'. Police admit that, even when suspects are able to show Indian identity documents, they are assumed to be false. ${ }^{73}$ By contrast, women from Sindh—both Hindu and Muslim—do not generate the same fears

\footnotetext{
${ }^{73} \mathrm{http}: / /$ indiatoday.intoday.in/story/bengali-speaking-girls-human-traffickingkutch-flesh-trade/1/213428.html, [accessed 16 April 2018].
} 
of contagion. Muslims from Sindh continue to live undocumented lives, while Hindus have recently been offered citizenship and a chance to live permanently-and legally-in India. What does this say about the selective process of treating marriage migrants? Is this about xenophobia and the fears of 'outsiders' contaminating the cultural composition of the nation? But then who are the 'insiders' and who the 'outsiders'? Borders are no longer the physical sites where issues of migration, sexuality, and citizenship intersect. The notion of insider/outsider has to be delinked from the state's physical borders, perhaps to discuss it in terms of 'differential exclusion' where 'differently positioned subjects of migration transform the boundaries of citizenship and interrupt the logic of the political, both of which are still rooted in the dichotomous forms of belonging'. ${ }^{74}$ These categories of belonging are constantly shifting. In the period of princely rule, marriageable women could be used as political capital or killed at birth; a lot of times, this depended on who their mothers were. As argued above, 'legitimate' daughters of official marriages were more likely to be killed among a people heavily invested in hypergamy, while those born of slave mothers might have been sent out as marriage migrants of an earlier time. During the nineteenth century, a stronger colonial state attempted to regulate slave traffic, even as they acknowledged it to be almost impossible once the boundaries between 'slavery' and the 'family' were blurred. The role of the state at different points in time, as it evaluates these border crossings of women for marriage, reminds us to be alert to the continuities shared by the contemporary state with its predecessors and to locate the territorial ruptures of partition in broader sociological and historical perspective.

${ }^{74}$ R. Andrijasevic, 'Sex on the Move: Gender, Subjectivity and Differential Inclusion', Subjectivity, vol. 29 (1), 2009, pp. 389-406. 